\title{
Studi Komparatif Pengetahuan Remaja tentang Penyimpangan Perilaku Seks di Desa dan di Kota
}

\author{
Ida Susila ${ }^{1}$ \\ ${ }^{1}$ Universitas Islam Lamongan \\ Email : idasusila18@gmail.com
}

Received 8 May 2018; Accepted 8 May 2018; Published 15 May 2018

\begin{abstract}
ABSTRAK
Era globalisasi membuka wacana sendiri bagi negara ini, termasuk pergeseran nilai dalam cara bergaul para remaja yang bebas dan cenderung tanap batas, selain ada dampak baik dan buruk dalam globalisasi dan pengaruhnya pada remaja, hal ini disebabkan dorongan seksual yang sedang berkembang pada masa remaja, perilaku seks pada remaja yang tidak sehat dapat berakibat buruk bagi remaja sendiri, misalnya: kehamilan diluar nikah, aborsi, terjadinya PMS, kematian AKI dan AKB, serta gangguan psikologi. Dalam penelitian ini variabelnya adalah pengetahuan penyimpangan perilaku seks, penelitian ini menggunakan metode deskriptif studi perbandingan (comparatif study), sampel penelitian ini 103 siswa SMA Yapita Surabaya dan 67 siswa MA Roudlotul Muta'abidin Lamongan. Dari hasil penelitian didapatkan gambaran pengetahuan tentang penyimpangan perilaku seks khususnya variabel pelecehan seksual, di SMA Yapita Surabaya sebesar $54(52,4 \%)$ dengan kriteria cukup dan di MA Roudlotul Muta'abidin Lamongan sebesar 36 (53, 7\%) dengan kriteria kurang. sehingga dapat disimpulkan tidak ada perbedaan penyimpangan perilaku seks baik di SMA Yapita Surabaya dan di MA Roudlotul Muta'abidin Lamongan. Sehingga perlu diadakan pendidikan seks khusus untuk remaja. Penelitian ini dapat digunakan sebagai rekomendasi untuk penelitian selanjutnya, dengan menggunakan sampel yang lebih besar dan meneliti gambaran mengenai kejadian penyimpangan perilaku seks pada variabel yang lain.
\end{abstract}

Kata Kunci : Pengetahuan, perilaku seks, penyimpangan.

Copyright $(92018$ STIKes Surya Mitra Husada

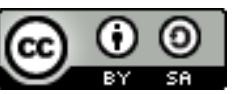

This is an open-acces article distributed under the terms of the Creative Commons Attribution-ShareAlike 4.0 International License. 


\section{PENDAHULUAN}

Dengan semakin pesatnya perkembangan teknologi dan alat-alat komunikasi, terjadilah perubahan-perubahan sosial alat yang sangat cepat pada hampir semua kebudayaan bangsa di dunia. Perubahan sosial yang diakibatkan oleh bervariasinya ide-ide ekonomi, religi dan ilmu pengetahuan itu mempengaruhi sekali adat kebiasaan hidup manusia, sekaligus juga mempengaruhi pola-pola seks yang konvensial, sedangkan pelaksanaan seks banyak dipengaruhi oleh penyebab perubahan urbanisasi, alat-alat kontrasepsi, lamanya pendidikan, demokratisasi fungsi wanita dalam masyarakat, dan macam-macam kebiasaan karakteristik lainnya dalam peradaban modern sekarang.

Era globalisasi membuka wacana sendiri bagi negara ini, termasuk pergeseran nilai dalam cara bergaul para remaja yang bebas dan cenderung tanpa batas. Selalu ada dampak baik dan buruk dalam globalisasi dan pengaruhnya pada pergaulan remaja (Ragnafilia, 2016). Hal itu menunjukkan bahwa seks bebas telah semakin dapat diterima oleh sebagian masyarakat.

Tidak bisa dipungkiri bahwa globalisasi yang membuat dunia menjadi tidak terbatas serta meningkatnya konsumenisme dikalangan remaja (berusia 15-24 Tahun) telah mereduksi (menurunkan) nilai keperawanan yang pada gilirannya memicu kian bebasnya model pergaulan para remaja. Mereka tidak lagi sekedar berpegangan tangan, berpelukan, berciuman, tetapi juga telah berhubungan seksual, sebuah aktivitas yang sesungguhnya "Hak milik" bagi yang sudah menikah (BKKBN, 2014).

Remaja masa kini memperlihatkan minat terhadap lawan jenisnya lebih awal dari pada beberapa puluh tahun yang lalu. Remaja antara usia 10 - 14 Tahun banyak menyatakan minatnya terhadap hal-hal seperti : dating, bicara tentang pacar, membenarkan adegan cinta dalam film (Yusuf, 2013).

Seiring dengan perkembangan organ-organ seksual, remaja mulai melirik hal lain. Perasaan ini semakin menjadi ketika muncul perasaan suka dan ingin lebih dekat dengan lawan jenis. (Bachtiar, 2014). Hal ini disebabkan dorongan seksual yang sedang berkembang pada masa remaja. Penyaluran dorongan ini tampak dalam bentuk pacaran. (Willis, 2015). Sekarang ini pacaran mengalami kemunduran, disebabkan tingkah laku para pelaku pacaran yang amoral dan asusila. (Azam, 2015).

Hasil penelitian yang dilakukan Objectively Indicator (OVI). Perkumpulan Keluarga Berencana Indonesia (PKBI) Jatim 2004 diperoleh hasil bahwa dengan kategori dengan usia 15-24 Tahun responden yang sudah melakukan hubungan seksual dengan satu orang atau lebih, yakni sebanyak $49(13,61 \%)$ orang dari 360 responden. Penelitian ini dilakukan oleh seluruh Youth Center PKBI seluruh Indonesia untuk mengungkap perilaku seks remaja.

Selama dua tahun terakhir, PKBI Jatim mencatat cukup banyak konsultasi seks remaja yang masuk ke remaja mereka. Tahun 2013, dari 102 konsultasi yang masuk 52 (51\%) $\begin{array}{lllll}\text { diantaranya melakukan hubungan diluar nikah, } 9 & (8,8 \%)\end{array}$ di antaranya positif hamil.

Angka konsultasi ini terus beranjak naik, sejak Januari - November 2014, tercatat 227 remaja yang melakukan konsultasi, $90(36,64 \%)$ di antaranya telah melakukan seks bebas dan $8(3,5 \%)$ orang positif hamil. Puncak jumlah remaja yang merupakan konsultasi berkaitan dengan seks pra-nikah ini terjadi pada bulan Agustus 2014. Dari 40 remaja yang berkonsultasi masalah seks, $20(50 \%)$ di antaranya telah menjalani seks bebas dan $1(2,5 \%)$ orang hamil. Hal serupa juga terjadi di bulan Mei dan Juni, dengan tingkatan pelaku pergaulan bebas 17 dan 10 orang.

Berdasarkan data laporan konseling (konsultasi) di PKBI Jatim sampai November 2014 adalah jenis konsultasi seks 227 remaja, seks pranikah (82), hamil di luar nikah (8), penyakit kelamin (3), kelainan fungsi seksual (21), homoseksual (10), dipaksa berhubungan (18), masturbasi (18), lain-lain (67) dan konsultasi pacaran 1.134. Hasil Penelitian di atas menunjukkan adanya suatu masalah perilaku seks pada remaja. (Dinas Informasi dan Komunikasi, 2014).

Masalah remaja tersebut hendaknya berfokus pada perubahan organobiologik akibat kematangan organ-organ reproduksi yang sering terjadi tidak diketahui oleh remaja sendiri. 
Perubahan ini akan memberikan dorongan psikologik dan emosional tertentu, yang jarang bahkan menimbulkan kebingungan dalam diri remaja. (Dep.Kes RI, 2010). Faktorfaktor yang diduga menjadi sebab terjadinya masalah remaja adalah adanya perubahanperubahan biologis dan psikologis, institusi pendidikan langsung yaitu orang tua dan guru sekolah kurang siap untuk memberikan informasi yang benar dan tepat waktu, perbaikan gizi yang menyebabkan umur haid pertama lebih dini, semakin majunya teknologi dan sarana komunikasi menyebabkan membanjirnya informasi dari luar yang sulit sekali diseleksi (Dep.Kes RI, 2010).

Perilaku seks pada remaja yang tidak sehat dapat berakibat buruk bagi remaja sendiri. Diantaranya : kehamilan diluar nikah, aborsi, terjadinya PMS (penyakit menular seksual), meningkatnya angka kematian ibu dan bayi, sampai gangguan psikologi yaitu depresi, ingin bunuh diri, dan sebagainya. Remaja merupakan generasi penerus bangsa yang berwawasan luas dan berdedikasi tinggi.

Pada kenyataannya, dari studi pendahuluan didapatkan data di SMA Yapita Surabaya dari 30 responden yang berpengetahuan tentang penyimpangan perilaku seks (pornografi, pelecehan seksual, masturbasi, homoseksualitas/ lesbianisme, free sex) : baik 12 (40\%), sedang 8 (26,6\%), rendah 10 (33\%) siswa. Sedangkan di MA Roudlotul Muta'abidin Payaman Solokuro Lamongan dari 30 responden yang berpengetahuan tentang penyimpangan perilaku seks tinggi 7(23\%) siswa, sedang $12(40 \%)$, rendah 11(37\%) siswa.

Dengan demikian diperlukan pendidikan seks untuk memperkuat dasar-dasar pengetahuan dan pengembangan kepribadian melalui pendidikan seks di harapkan timbulnya sikap emosional yang sehat dan bertanggung jawab terhadap seks. (Gunarsa, 2010).

Untuk memecahkan berbagai peroblem itu. Berbagai lembaga yang mengkhususkan pada konseling bagi remaja sudah menjamur, surat kabar dan majalah banyak terbit untuk penuntun hidupnya. Tidak ketinggalan berbagai seminar talk show dan lokakarya di rasakan manfaatnya oleh para remaja, mereka penuh teka-teki dan unik. Sehingga karakter mereka diberbagai daerah memiliki perbedaan sehingga penelitian tentang remaja hingga kini tak pernah tuntas. Para psikolog berbeda pendapat jika mengomentari kenakalan remaja, karena itu, menghadapi remaja perlu kerjasama semua elemen termasuk psikolog dan ulama.

Berpijak dari kondisi penelitian ini peneliti mengambil judul "Studi Komparatif Pengetahuan Remaja Tentang Penyimpangan Perilaku Seks di SMA Yapita Surabaya Dan di MA Roudlotul Muta'abidin Solokuro Lamongan".

\section{METODE PENELITIAN}

Berdasarkan jenis penelitian ini, peneliti ingin mengetahui perbedaan pengetahuan remaja tentang penyimpangan perilaku seks di SMA Yapita Surabaya dan di MA Roudlotul Muta'abidin Payaman Solokuro Lamongan. Jenis penelitian yang digunakan adalah studi perbandingan (Comparative Study). populasi yang diambil dari SMA Yapita Surabaya adalah 140, sedangkan di MA Roudlotul Muta'abidin Payaman Solokuro Lamongan adalah 80. Besar Sampel dapat menggunakan rumus seperti berikut:

$$
\mathrm{n}=\frac{\mathrm{N}}{1+\mathrm{N}\left(\mathrm{d}^{2}\right)}
$$

Jadi besar penelitian diperkotaan adalah 103 responden. Jadi besar sampel penelitian dipedesaan adalah 67 responden.

Sampling pada penelitian ini menggunakan teknik purposive. Tempat penelitian di SMA Yapita Surabaya yang bertempat di daerah perkotaan dan MA Roudlotul Muta'abidin Desa Payaman Solokuro Lamongan. Waktu penelitian ini dimulai pada bulan Januari sampai dengan bulan Maret. Pengumpulan data menggunakan kuesioner yang diberikan kepada siswa. 


\section{HASIL PENELITIAN}

Tabel 1. Gambaran Pengetahuan Penyimpangan Perilaku Seks Remaja

\begin{tabular}{|c|c|c|c|c|c|c|c|c|c|c|c|c|}
\hline \multirow[t]{2}{*}{ Variabel } & \multicolumn{6}{|c|}{$\begin{array}{l}\text { SMA Yapita } \\
\text { Surabaya }\end{array}$} & \multicolumn{6}{|c|}{$\begin{array}{l}\text { MA Roudlotul Muta'abidin } \\
\text { Lamongan }\end{array}$} \\
\hline & B & $(\%)$ & $\mathrm{C}$ & $(\%)$ & $\mathbf{K}$ & $(\%)$ & $\mathbf{B}$ & $\%$ & $\mathbf{C}$ & $\%$ & $\mathbf{K}$ & $\%$ \\
\hline -Pornografi & 23 & $(22,3)$ & 52 & $(50,5)$ & 28 & $(27,2)$ & 15 & $(22,4)$ & 32 & $(47,8)$ & 20 & $(29,9)$ \\
\hline -Pelecehan seksual & 4 & $(3,9)$ & 54 & $(52,4)$ & 45 & $(43,7)$ & 8 & $(11,9)$ & 23 & $(34,3)$ & 36 & $(53,7)$ \\
\hline -Masturbasi & 20 & $(19,4)$ & 45 & $(43,7)$ & 38 & $(36,9)$ & 11 & $(16,4)$ & 29 & $(43,3)$ & 27 & $(40,3)$ \\
\hline -Homoseks/Lesbian & 28 & $(27,2)$ & 47 & $(45,6)$ & 28 & $(27,2)$ & 11 & $(16,4)$ & 27 & $(40,3)$ & 29 & $(43,3)$ \\
\hline -FreeSex & 35 & $(34,0)$ & 42 & $(40,8)$ & 26 & $(25,2)$ & 15 & $(22,4)$ & 31 & $(46,3)$ & 21 & $(31,3)$ \\
\hline
\end{tabular}

Berdasarkan tabel 1. diatas dapat dilihat bahwa pengetahuan penyimpangan perilaku seks pada variabel pornografi di SMA Yapita Surabaya sebagian besar $52(50,5 \%)$ responden, sedangkan di MA Roudlotul Muta'abidin Lamongan sebagian besar responden 32 (47,8\%). Pada variabel pelecehan seksual di SMA Yapita Surabaya sebagian besar $54(52,4 \%)$ responden, sedangkan di MA Roudlotul Muta'abidin Lamongan sebagian besar responden 36(53,7\%). Pada variabel masturbasi di SMA Yapita Surabaya sebagian besar 45(43,7\%) responden, sedangkan di MA Roudlotul Muta'abidin Lamongan sebagian besar 29(43,3\%) responden. Pada variabel homoseksual/lesbian di SMA Yapita Surabaya sebagian besar 47(45,6\%) responden, sedangkan di MA Roudlotul Muta'abidin Lamongan sebagian besar $29(43,3 \%)$ responden. Pada variabel free seks di SMA Yapita Surabaya sebagian besar $42(40,8 \%)$ responden, sedangkan di MA Roudlotul Muta'abidin Lamongan sebagian besar $31(46,3 \%)$ responden.

Sehingga dapat disimpulkan bahwa sebagian besar responden mempunyai gambaran pengetahuan tentang penyimpangan seks pada variabel pelecehan seksual yaitu pada kriteria cukup sebesar $54(52,4 \%)$ untuk SMA Yapita Surabaya, sedangkan untuk MA Roudlotul Muta'abidin Lamongan sebesar $36(53,7 \%)$ pada variabel pelecehan seksual dengan kriteria kurang.

\section{Analisis Perbedaan Pengetahuan Perilaku Seks di SMA Yapita Surabaya dan di MA Roudlotul Muta'abidin Lamongan}

Maka dapat dilihat tabel 1. perbedaan pengetahuan penyimpangan perilaku seks pada variabel pornografi di SMA Yapita Surabaya sebagian besar 23 (22,3\%) responden, sedangkan di MA Roudlotul Muta'abidin Lamongan sebagian besar responden 15 (22,4\%). Pada variabel pelecehan seksual di SMA Yapita Surabaya sebagian besar $4(3,9 \%)$ responden, sedangkan di MA Roudlotul Muta'abidin Lamongan sebagian besar responden 8(11,9\%). Pada variabel masturbasi di SMA Yapita Surabaya sebagian besar 20(19,4\%) responden, sedangkan di MA Roudlotul Muta'abidin Lamongan sebagian besar 11(16,4\%) responden. Pada variabel homoseksual/lesbian di SMA Yapita Surabaya sebagian besar 28(27,2\%) responden, sedangkan di MA Roudlotul Muta'abidin Lamongan sebagian besar 11(16,4\%) responden. Pada variabel free seks di SMA Yapita Surabaya sebagian besar 35(34,0\%) responden, sedangkan di MA Roudlotul Muta'abidin Lamongan sebagian besar 15(22,4\%) responden. 


\section{PEMBAHASAN}

\section{Gambaran Pengetahuan Responden}

Berdasarkan tabel 1. dapat diketahui bahwa sebagian besar $54(52,4 \%)$ pengetahuan siswa di SMA Yapita Surabaya tentang penyimpangan perilaku seks pada variabel pelecehan seksual dengan kriteria cukup. Sedangkan pengetahuan siswa MA Roudlotul Muta'abidin Lamongan tentang penyimpangan perilaku seks dengan variabel pelecehan seksual sebesar $36(53,7 \%)$ dengan kriteria kurang. Sehingga dapat diketahui baik di SMA Yapita Surabaya dan MA Roudlotul Muta'abidin Lamongan mereka kurang mengetahui tentang bentuk perilaku penyimpangan seks khususnya variabel pelecehan seksual.

Menurut Abu Al-Ghifari pelecehan seksual paling sering terjadi pada teman dekat atau seseorang yang pernah dikenalnya, sekalipun tidak melakukan hubungan seksual namun tindakan seperti ini jelas merendahkan kehormatan seseorang. Pelecehan seksual juga merupakan dampak dari ketidakmampuan seseorang dalam mengendalikan hawa nafsu terhadap lawan jenis sebagai obyek pelampiasan, tanpa melihat keberadaannya sebagai manusia yang bermoral, terlebih lagi tidak ada seseorang yang mau direndahkan.

Pada remaja menganggap pelecehan seksual sekedar iseng, tapi manakala nilai kehormatan itu diganggu dalam pengertian dihinakan atau di perlakukan tidak sesuai dengan norma yang dianut seseorang, maka hal seperti itu termasuk pelecehan seksual.

Dalam penyuluhan muda-mudi perlu dibahas secara singkat variasi dan penyimpangan seksual yang masih dianggap dalam batas-batas normal perlu dikemukakan. Semua itu dilakukan dengan latar belakang norma-norma yang sedang berlaku, termasuk agama dan pandangan masyarakat.

Apabila remaja dapat memperoleh pemahaman yang baik tentang aspek-aspek pokok identitas dirinya seperti fisik, kemampuan intelektual, emosi, sikap dan nilai-nilai, maka dia akan siap berfungsi yang sehat baik dengan teman sebaya, keluarga atau masyarakat dewasa tanpa dibebani perasaan cemas dan frustasi. Disamping itu, mungkin remaja melihat bahwa tidak sedikit orang dewasa atau masyarakat sekitarnya yang gaya hidupnya yang kurang memperdulikan agama, bersifat munafik, tidak jujur dan perilaku amoral lainnya. Pernyataan ini didukung oleh teori Syamsu (2000) yang mengemukakan bahwa remaja dapat dipandang telah memiliki identity yang matang (sehat), apabila sudah memiliki pemahaman dan kemampuan untuk menyesuaikan diri dengan diri sendiri, peran-perannya dalam kehidupan sosial (lingkungan keluarga keluarga, sekolah atau masyarakat) dunia kerja dan nilai-nilai agama.

\section{Analisis Perbedaan Pengetahuan Penyimpangan Seksual}

Untuk mengetahui perbedaan pengetahuan remaja tentang penyimpangan perilaku seks di SMA Yapita Surabaya dan MA Roudlotul Muta'abidin Lamongan maka Maka dapat dilihat tabel 5.1 pengetahuan penyimpangan perilaku seks pada variabel pornografi di SMA Yapita Surabaya sebagian besar $52(50,5 \%)$ responden dengan kriteria cukup, sedangkan di MA Roudlotul Muta'abidin Lamongan sebagian besar responden 32 (47,8\%) dengan kriteria kurang artinya ada perbedaan pengetahuan pornografi di SMA Yapita Surabaya dan di MA Roudlotul Muta'abidin Lamongan. Pada variabel pelecehan seksual di SMA Yapita Surabaya sebagian besar $54(52,4 \%)$ responden dengan kriteria cukup, sedangkan di MA Roudlotul Muta'abidin Lamongan sebagian besar responden 36(53,7\%) dengan kriteria kurang artinya ada perbedaan pengetahuan pelecehan seksual di SMA Yapita Surabaya dan di MA Roudlotul Muta'abidin Lamongan. Pada variabel masturbasi di SMA Yapita Surabaya sebagian besar 45(43,7\%) responden dengan kriteria cukup, sedangkan di MA Roudlotul Muta'abidin Lamongan sebagian besar 29(43,3\%) responden dengan kriteria cukup artinya tidak ada perbedaan pengetahuan masturbasi di SMA Yapita Surabaya dan di MA Roudlotul Muta'abidin Lamongan. Pada variabel homoseksual/lesbian di SMA Yapita Surabaya sebagian besar 47(45,6\%) responden dengan kriteria cukup, sedangkan di MA Roudlotul Muta'abidin Lamongan sebagian besar 29(43,3\%) responden dengan kriteria kurang artinya 
ada perbedaan pengetahuan homoseksual/lesbian di SMA Yapita Surabaya dan di MA Roudlotul Muta'abidin Lamongan. Pada variabel free seks di SMA Yapita Surabaya sebagian besar 42(40,8\%) responden dengan kriteria cukup, sedangkan di MA Roudlotul Muta'abidin Lamongan sebagian besar 31(46,3\%) responden dengan kriteria cukup. Artinya tidak ada perbedaan pengetahuan free sex di SMA Yapita Surabaya dan di MA Roudlotul Muta'abidin Lamongan.

Sesuai dengan pendapat Sarwono Prawirohardjo, bahwa pendidikan seksual peranan utama dipegang oleh para orang tua dan para guru, maka dalam buku pelajaran ini titik berat lebih ditekankan pada penyuluhan seksual, selain pengetahuan seksologi perlu juga diperhatikan norma-norma kehidupan yang sedang berlaku dalam masyarakat pada waktu itu, yang berbeda-beda bagi setiap bangsa, bahkan berbeda pula bagi setiap suku dalam suatu bangsa, perlu disadari. Perlu disadari bahwa norma-norma kehidupan itu tidak statis sifatnya. Melainkan dapat berubah-ubah dari zaman ke zaman.

Penyuluhan yang berkaitan dengan agama tidak dapat diabaikan perbedaan letak geografis dapat mempengaruhi remaja dalam memperoleh pengetahuan, di SMA Yapita Surabaya yang letaknya diperkotaan maka semakin mudah untuk mendapatkan informasi dengan semakin majunya teknologi dan sarana telekomunikasi yang dapat menyebabkan membanjirnya informasi dari luar yang sulit sekali di seleksi (Depkes RI, 1994). Sedangkan di MA Roudlotul Muta'abidin Lamongan yang bertempat di pedesaan untuk mendapatkan informasi pengetahuan penyimpangan perilaku seks masih terbatas.

\section{Analisis Perbedaan Penyimpangan Perilaku Seks}

Untuk mengetahui perbedaan penyimpangan perilaku seks (pornografi, pelecehan seksual, masturbasi, homoseksual / lesbian dan free sex di SMA Yapita Surabaya dan di MA Roudlotul Muta'abidin dapat dilihat pada tabel 5.4 penyimpangan perilaku seks pada variabel pornografi di SMA Yapita Surabaya sebagian besar $71(68,9 \%)$ responden dengan kriteria kurang baik, sedangkan di MA Roudlotul Muta'abidin Lamongan sebagian besar responden $51(76,9 \%)$ dengan kriteria kurang baik artinya tidak ada perbedaan perilaku pornografi di SMA Yapita Surabaya dan di MA Roudlotul Muta'abidin Lamongan. Pada variabel pelecehan seksual di SMA Yapita Surabaya sebagian besar 71 (68,9\%) responden dengan kriteria kurang baik, sedangkan di MA Roudlotul Muta'abidin Lamongan sebagian besar responden $45(67,2 \%)$ dengan kriteria kurang baik artinya tidak ada perbedaan perilaku pelecehan seksual di SMA Yapita Surabaya dan di MA Roudlotul Muta'abidin Lamongan. Pada variabel masturbasi di SMA Yapita Surabaya sebagian besar 72 (69,9\%) responden dengan kriteria kurang baik, sedangkan di MA Roudlotul Muta'abidin Lamongan sebagian besar 45 (67,2\%) responden dengan kriteria kurang baik artinya tidak ada perbedaan perilaku masturbasi di SMA Yapita Surabaya dan di MA Roudlotul Muta'abidin Lamongan. Pada variabel homoseksual/lesbian di SMA Yapita Surabaya sebagian besar 103 (100\%) responden dengan kriteria baik, sedangkan di MA Roudlotul Muta'abidin Lamongan sebagian besar 67 (100\%) responden dengan kriteria baik artinya tidak ada perbedaan perilaku homoseksual/lesbian di SMA Yapita Surabaya dan di MA Roudlotul Muta'abidin Lamongan. Pada variabel free seks di SMA Yapita Surabaya sebagian besar 103 (100\%) responden dengan kriteria baik, sedangkan di MA Roudlotul Muta'abidin Lamongan sebagian besar 67(100\%) responden dengan kriteria baik. Artinya tidak ada perbedaan perilaku free sex di SMA Yapita Surabaya dan di MA Roudlotul Muta'abidin Lamongan.

Pada variabel pornografi, pelecehan seks dan masturbasi artinya tidak ada perbedaan penyimpangan perilaku seks di SMA Yapita Surabaya dan di MA Roudlotul Muta'abidin Lamongan dari ketiga variabel tersebut dengan kriteria kurang baik. Namun pada variabel homoseksual / lesbian dan free seks tidak dapat dianalisa karena mempunyai nilai yang sama, dengan kriteria baik, artinya tidak ada perilaku penyimpangan seks tersebut yang dilakukan oleh siswa di SMA Yapita Surabaya dan di MA Roudlotul Muta'abidin Lamongan.

Menurut dr. Boyke Dian Nugraha, DSOG. Hal ini disebabkan karena kurangnya pemahaman tentang pendidikan seksual yang sehat, dan bisa dipengaruhi oleh teman sebaya. Para orang tua dan guru sering kali tidak enak dengan pendidikan seks. Karena mereka yakin 
bahwa anak-anak muda akan jadi aktif secara seksual setelah memperoleh informasi, apabila aktivitas seksual terjadi orang tua dan guru mungkin merasa bertanggung jawab atau merasa bersalah. Selain pengaruh teman sebaya juga dipengaruhi oleh budaya metropolitan yang menyimpang dari agama dan keyakinan serta kurangnya melakukan kegiatan positif untuk mengalihkan gejolak emosional remaja yang cenderung ingin menyalurkan kebutuhan seksualnya dengan cara melakukan pelecehan seksual pornografi dan masturbasi.

SMA Yapita Surabaya yang letaknya diperkotaan maka semakin mudah untuk mendapatkan informasi tentang masturbasi, homoseksual/lesbian dan free sex, dengan semakin majunya teknologi dan sarana telekomunikasi yang dapat menyebabkan membanjirnya informasi dari luar yang sulit sekali di seleksi (Depkes RI, 2010). Sedangkan di MA Roudlotul Muta'abidin Lamongan yang bertempat di pedesaan untuk mendapatkan informasi pengetahuan penyimpangan perilaku seks khususnya variabel masturbasi, homoseksual/lesbian dan free sex masih terbatas, sehingga ada perbedaan pengetahuan tentang penyimpangan seks di SMA Yapita Surabaya dan di MA Roudlotul Muta'abidin Lamongan.

\section{Analisis Perbedaan Penyimpangan Perilaku Seks}

\section{Pornografi}

Penyimpangan perilaku seks pada variabel pornografi di SMA Yapita Surabaya sebagian besar $32(13,1 \%)$ responden, sedangkan di MA Roudlotul Muta'abidin Lamongan sebagian besar responden $16(23,9 \%)$ artinya siswa yang tidak melakukan perilaku pornografi di SMA Yapita Surabaya lebih banyak dari pada di MA Roudlotul Muta'abidin Lamongan, bisa juga di pengaruhi oleh banyaknya tontonan yang vulgar di daerah perkotaan, sehingga mereka tidak tertarik lagi dengan hal yang berbau pornografi.

\section{Pelecehan Seksual}

Penyimpangan perilaku seks pada variabel pelecehan seksual di SMA Yapita Surabaya sebagian besar $32(31,1 \%)$ responden baik, sedangkan di MA Roudlotul Muta'abidin Lamongan sebagian besar responden $22(32,8 \%)$ artinya siswa di MA Roudlotul Muta'abidin Lamongan yang tidak melakukan perilaku pelecehan seksual lebih banyak dan pada di SMA Yapita Surabaya.

Perilaku pelecehan seksual di surabaya lebih banyak terjadi dari pada di MA Roudlotul Muta'abidin Lamongan, perilaku penyimpangan seperti ini sangat bertentangan dengan norjma susila dan tidak sejalan dengan fitrah sosial yang saling membantu dan memahami perasaan orang lain. Mereka tidak sadar bahwa orang lain pun memiliki perasaan dan hak merdeka yang sama, bahkan para siswa tidak berfikir, bagaimana jika keluarganya sendiri yang mengalami korban pelecehan seksual.

\section{Masturbasi}

Penyimpangan perilaku seks pada variabel masturbasi di SMA Yapita Surabaya sebagian besar $31(30,1 \%)$ responden, sedangkan di MA Roudlotul Muta'abidin Lamongan sebagian besar $22(32,8 \%)$ responden artinya siswa di MA Roudlotul Muta'abidin Lamongan yang tidak melakukan perilaku masturbasi lebih banyak dari pada di SMA Yapita Surabaya.

Angka kejadian masturbasi di SMA Yapita Surabaya lebih tinggi dari pada di MA Roudlotul Muta'abidin Lamongan, sesuai dengan pendapat Abu Al ghifari penyebabnya adalah kian gencarnya media cetak dan elektronik yang menyajikan menu seks secara vulgar dan menjamurnya peredaran VCD porno. Terbukti, saat diinterogasi, para pelaku masturbasi itu mengaku melakukan perbuatan nista itu setelah menonton film porno, tak kalah pentingnya, norma-norma islam kian memudar, sebagai imbas gencarnya arus informasibarat yang masuk. Sementara itu pendidikan agama di sekolah-sekolah urnum terus dikurangi. Akibatnya, generasi muda kian semakin rentan terhadap berbagai penyimpangan seks. 
Menurut dr. Boyke Dian Nugraha, DSOG. Hal ini disebabkan karena kurangnya pemahaman tentang pendidikan seksual yang sehat, dan bisa dipengaruhi oleh teman sebaya. Para orang tua dan guru sering kali tidak enak dengan pendidikan seks. Karena mereka yakin bahwa anak-anak muda akan jadi aktif secara seksual setelah memperoleh informasi, apabila aktivitas seksual terjadi orang tua dan guru mungkin merasa bertanggung jawab atau merasa bersalah. Selain pengaruh teman sebaya juga dipengaruhi oleh budaya metropolitan yang menyimpang dari agama dan keyakinan serta kurangnya melakukan kegiatan positif untuk mengalihkan gejolak emosional remaja yang cenderung ingin menyalurkan kebutuhan seksualnya dengan cara melakukan pelecehan seksual pornografi dan masturbasi.

\section{Homoseksual/Lesbian dan Free Sex}

Penyimpangan perilaku seks pada variabel homoseksual/lesbian di SMA Yapita Surabaya sebagian besar 103 (100\%) responden, sedangkan di MA Roudlotul Muta'abidin Lamongan sebagian besar $67(100 \%)$ responden. Pada variabel free seks di SMA Yapita Surabaya sebagian besar $103(100 \%)$ responden, sedangkan di MA Roudlotul Muta'abidin Lamongan sebagian besar 67(100\%)

responden. Artinya tidak ada perbedaan perilaku free sex di SMA Yapita Surabaya dan di MA Roudlotul Muta'abidin Lamongan.

Homoseksual/lesbian dan free sex bukan saja merusak martabat manusia, tetapi juga dengan sengaja mensejajarkan diri dengan binatang, sesuai denagn hasil penelitian ini bahwa homosksual/lesbian dan free sex tidak terjadi di dua institusi ini. Dapat di pengaruhi oleh faktor dari kualitas diri remaja itu sendiri, seperti: baik dalam mendalami norma agama, berada dalam kelompok yang baik an memiliki perkembangan emosional yang sehat, selain itu kualitas lingkungan keluarga dalam mengembangkan norma positif seperti pendidikan dan kebiasaan melakukan norma agama juga didukung oleh lingkungan sekolah yang berbasis agama kuat.

\section{KESIMPULAN DAN SARAN}

\section{Kesimpulan}

Hasil penelitian 103 responden di SMA Yapita Surabaya sebagian besar pengetahuan responden tentang penyimpangan perilaku seks dengan kriteria cukup, dan 67 responden di MA Roudlotul Muta'abidin Lamongan sebagian besar pengetahuan responden tentang penyimpangan perilaku seks dengan kriteria kurang.

Pengetahuan remaja tentang penyimpangan perilaku seks (pornografi, pelecehan seksual, masturbasi, homoseksual / lesbian dan free sex) di SMA Yapita Surabaya dan di MA Roudlotul Muta'abidin Lamongan sebagian besar responden berusia 15 - 16 Tahun.

Pengetahuan remaja tentang penyimpangan perilaku seks (pornografi, pelecehan seksual, masturbasi, homoseksual / lesbian dan free sex) di SMA Yapita Surabaya dan di MA Roudlotul Muta'abidin Lamongan sebagian besar berjenis kelamin laki-laki.

Ada perbedaan pengetahuan penyimpangan perilaku seks di SMA Yapita Surabaya dan di MA Roudlotul Muta'abidin Lamongan pada variabel pornografi, pelecehan seks dan homoseksual/lesbian, sedangkan pengetahuan pada variabel masturbasi dan free seks tidak ada perbedaan. 


\section{Saran}

Diharapkan masyarakat khususnya orang tua lebih memperhatikan anaknya dalam memberikan pendidikan agama, agar tidak mudah terpengaruh oleh hal-hal yang tidak baik bagi perkembangan seksualnya. Bagi lembaga pendidikan diharapkan memberikan tambahan informasi tentang pendidikan seks yang sehat, dan tidak beranggapan bahwa seks itu hal yang tabu untuk dibicarakan.

\section{DAFTAR PUSTAKA}

Al. Ghifari, \& Abu. (2012). Pernikahan Dini Dilema Generasi Ekstravaganza. Mujahid press. Bandung. 2015. Bengkel Cinta \& Problematika Remaja Antara Cinta, Seks dan Jodoh. Mujahid Press. Bandung. , 2016. Bengkel Cinta (Tanya Jawab Remaja

Tentang cinta, Jodoh dan Seks). Mujahid Press. Bandung.

Ali, M., \& Asrori. (2014). Psikologi Perkembangan Remaja Peserta Didik. Bumi Aksara. Jakarta.

Ali-Mukaffi. (2014). Pacaran Dalam Kacamata Islam. Penerbit Media Da’wah. Jakarta.

Arikunto. (2010). Prosedur Penelitian. Rineka Cipta. Jakarta.

Azam. (2015). Siapa Bilang Pacaran Haram?. Penerbit Quranic Media Pustaka. Jogjakarta.

Bachtiar. (2014). Cipta Remaja Mengungkap Pola dan Perilaku Cinta Remaja. Penerbit Saujana. Jogjakarta.

Danim, \& Sudarman. (2013). Metode Penelitian Kebidanan. EGC. Jakarta.

Depkes RI. (2010). Pola Pembinaan Kesehatan Reproduksi Remaja Dalam Pembinaan Kesehatan Keluarga. Depkes. Jakarta.

Forum. Ragnafilia.com. 21 Januari 2016.

Gunarsa, \& Singgih, D. (2010). Psikologi Praktek Anak, Remaja dan Keluarga. BPK Gunung Mulia. Jakarta.

Hidayat, A., \& Aziz, A. (2016). Pengantar Kebutuhan Dasar Manusia : Aplikasi Konsep Dan Proses Keperawatan. Salemba Medika. Jakarta.

Hurlock, E.B. (2008). Psikologi Perkembangan. Penerbit Erlangga. Jakarta.

Kartono, \& Kartini. (2016). Psikologi Wanita Mengenal Gadis Remaja Dan Wanita Dewasa. Mandar maju. Bandung.

Muhammad. (2008). Kontradiksi Dalam Kesehatan Reproduksi. Penerbit Pustaka Sinar Harapan. Jakarta.

Notoatmodjo, S. (2013). Ilmu Kesehatan Masyarakat. Rineka Cipta. Jakarta. 2012 Metodologi Penelitian Kesehatan. Rineka Cipta. Jakarta.

Nursalam, \& Pariani. (2013). Pendekatan Praktis Metodologi Riset Keperawatan. CV. Sagung Seto. Jakarta. 
Willis, \& Sofyan, S. (2010). Permasalahan Remaja dan Pemecahannya. Penerbit Angkasa. Bandung.

Yusuf, S. (2010). Psikologi Perkembangan Anak dan Remaja. Penerbit PT Remaja Rosdakarya. Bandung.

Yusuf. (2013). Bercinta Karena Allah. Kawasan Pustaka. Jakarta. 